\title{
Oskar Wolski
}

\section{Smart Villages in EU Policy: How to Match Innovativeness and Pragmatism?}

\begin{abstract}
Smart Villages is an approach to rural development which has been under discussion in the EU as one of the subthemes that the ENRD is working on. For this reason, the Thematic Group (TG) on Smart Villages was launched in 2017. Since then it has been contributing to the definition of smart villages, discussing the changes in rural development policy and opportunities for providing support for smart villages, exchanging experience and best practices in smart rural development, and serving as a forum for dialogue between various rural stakeholders. This paper outlines the discussion held during the selected meetings of the TG and briefly indicates the academic background of the approach discussed. Its aim was to present Smart Villages in terms of EU policy. Hence, the paper presents the genesis of the EU debate, highlights some of the dilemmas of the definition of smart villages, indicates the role of the territorial governments and the EU in creating the conditions for implementing the approach, and shows the selected examples of smart rural development. Smart Villages is an alternative way of thinking about the quality of rural life, and it seems to respond to the way the EU policy is evolving. However, it calls for better tailored tools and instruments, which applies both to EU policies and national/regional sources. It also calls for regional and local governments to play their role in the process.
\end{abstract}

Keywords: smart villages, smart rural development, rural development policy, European Union (EU) policy, European Network for Rural Development (ENRD).

Oskar Wolski, PhD Candidate, Faculty of Geographical Sciences, University of Łódź, Łódź, oskwolski@ gmail.com.

Alongside the references and the author's own knowledge, the paper uses information obtained during the participation in the meetings of the Thematic Group on Smart Villages, acting under the European Network for Rural Development (ENRD) in Brussels. Hence, the paper partly expresses the opinions of the participants of the meetings as well. The reports on the meetings of the TG, in which the author took part and were later used in preparation of this paper, are available at: http://ksow.pl/news/entry/13128-innowacjespoleczne-i-cyfrowe-na-obszarach-wiej.html and http://ksow.pl/news/entry/13373-realizacja-uslug-naobszarach-wiejskich-za-pomo.html (access: September 2018). The author's participation was financed by the Foundation of Assistance Programmes for Agriculture FAPA and the Agricultural Advisory Centre in Brwinów, Branch Office in Warsaw, serving as the Central Unit of the National Rural Network (KSOW) in Poland. The paper reflects the author's view, which does not purport to reflect the opinions of the KSOW. 


\section{Introduction}

Smart Villages ${ }^{1}$ is an approach to rural local development which exemplifies current dynamic and direction of the development processes and civilisational challenges. It has its origin not only in observing rural reality, but also in an academic debate (Naldi et al. 2015; Zwolińska-Ligaj, Guzal-Dec and Adamowicz 2018), which sometimes follows the debate on smart cities (Visvizi and Lytras 2018). Smart villages are those where action is based on the following foundations: community, co-creation, locality and adjustment. They are realised by people and for people, in cooperation with the public, social, business, and academic sectors (co-creation). They are also adjusted to communities' needs (humancentred design) and local development challenges. Implemented on the local level, they fit into local socio-economic conditions (place-based approach). Along with the EU Action for Smart Villages, the concept, which started in 2017, has been part of the European-wide debate on rural development and is one of the sub-themes addressed by the European Network for Rural Development (ENRD). In practice, it is not a fashionable term that attracts public attention; within the realm of the EU policy, it is much more: the discussion on the smart villages stems from the fact that the existing approaches to rural development do not include many of the current features of the countryside, its environment and society.

Most of all, Smart Villages seems to be a bridge between an unconventional way of thinking of the rural future and a pragmatic programming of rural development (cf. Visvizi and Lytras 2018). This is the context in which it is presented in the paper, which outlines the discussion during selected meetings of the Thematic Group (TG) on Smart Villages, which has been acting under the European Network for Rural Development (ENRD) in Brussels. Where appropriate the paper indicates the academic background of the Smart Villages approach. Hence, the aim of the paper is to present it in practical terms with regard to EU policy. ${ }^{2}$ Besides highlighting selected aspects of the EU discussion on smart rural development, discussing dilemmas of defining the term, and indicating the role of the regional/ local governments and the EU in creating the conditions for implementing the approach, it presents selected examples of projects implemented by smart villages.

1 In the paper, I use "Smart Villages" to refer to the name of the approach I discuss and "smart villages" to refer to the group of villages which try to implement and follow the approach.

2 Though it must be noted that the EU is not alone in starting the Smart-Villages initiatives. A review of these can be found in the paper by V. Zavratnik, A. Kos and E. Stojmenova Duh (2018). 


\section{Smart Villages in EU Policy: Outline}

It is an indisputable fact that the countryside has been undergoing dynamic changes. Not only do these relate to transitions in the rural economy (development of non-agricultural functions, e.g. Baldock et al. 2001; Galdeano-Gómez, AznarSánchez and Pérez-Mesa 2011; Marsden 1999; van der Ploeg et al. 2000; Terluin 2003), but also to changes in the perception of rural reality (perceiving it both as a space of production-of agriculture and consumption-which is a place of tourist, recreational, cultural and social activity, and which makes it possible to be in the natural environment, e.g. Crouch 2006; Halfacree 2012; Marsden 1999; Murdoch and Pratt 1993) and in a social fabric (migration processes connected to urbanisation and counterurbanisation, e.g. Boyle and Halfacree 1998). These are also overlapped by the global transitions in the economy and society, followed by the pressure of advanced civilisation. Nowadays, the focus is on the pace and direction of these changes-which, depending on the location, may interrelate. The question is therefore not how to fit into the changing reality in general (and not only because such a question is too broad to answer), but as follows: first, how to face the challenges which arise as a consequence of the dynamics of the changes in the countryside, its linkages to the city, and of its institutional environment and socio-economic conditions in which it exists; second, how to react adequately to the direction of change, given the protection of the good and resource which the countryside represents. This illustrates why the actions taken must be innovative, flexible, sustainable, and cost-effective, and why they must have the potential to act as a catalyst of further positive change in the environment.

Changes contain risk but also opportunities. Is there an approach to rural development management which can meet them? A model which does not focus on managing risk, but brings out the full potential of rural areas and thus strengthens their opportunities for development in the times of dynamic transition?

During the 2014-2020 programme period, the ENRD has been working, among others, on the Smart and Competitive Rural Areas theme. It responds the three EU Rural Development policy priorities, which are compatible with the changes presented in the countryside:

1. Fostering knowledge transfer and innovation in agriculture, forestry, and rural areas;

2. Enhancing farm viability and competitiveness of all types of agriculture in all regions and promoting innovative farm technologies and the sustainable management of forests;

3. Promoting food-chain organisation, including processing and marketing of agricultural products, animal welfare and risk management in agriculture. 
As a part of this work, the attention is on the following sub-themes: Food and Drink Supply Chains, Rural Businesses, and Smart Villages.

The Smart Villages sub-theme relates mostly to the first of the EU policy priorities mentioned, where innovativeness in rural areas is core. This brings together "smart" and "innovative". However, what is innovativeness for smart villages on the EU level? Essentially, smart villages can be understood as communities which refuse to wait for change to happen to them, and instead they take the initiative (ENRD 2018). Consequently, they are proactive and not reactive. Such an attitude is the opposite of a scheme where the beneficiaries are passive recipients and not stakeholders, and was a basis for developing the idea of Smart Villages. Smart communities explore practical solutions to the challenges they face and try to seize new opportunities (ENRD 2018). Exactly these kinds of village can meet the dynamics and direction of the contemporary changes in the countryside. The challenges may vary from village to village, however, what is important is the way they rise to them.

At the same time, the Smart Villages is not off base; it is intended to face the cycle of rural decline (BBC 2014; ENRD 2018; OECD 2006; Ward and Brown 2009). According to this, the countryside struggles with a lack of critical mass of demand for services and infrastructure that would enhance development, since investment in their provision is not cost-effective. This leads to a lower rate of business creation and reduced investment attractiveness. Further, slowing of economic development results in changes in the job market and employmentshortage of jobs, lack of an enterprise-friendly environment. This reinforces current, largely economic, emigration from rural areas. Most often, this concerns people of productive age who leave the rural areas, where the percentage of people of postproductive age increases as a result. On this account, the emigration itself is not the sole problem; the problem of ageing of the rural population arises directly from it. Finally, the population density decreases, and there is even less critical mass of users of services and infrastructure (Figure 1). In fact, a presentation of the process can start and finish at almost any point.

It is difficult to say what is a cause and what is an effect in this process. The problems described are common to all rural areas (Bajer 2012) but are specific on the local level, hence the context is what any "smart" approach must consider (Visvizi and Lytras 2018). Assuming that the problems are of a vicious-cycle nature, it can be implied that: first, the cycle may begin after any of the causes (effects) are triggered; second, the cycle may also cease after any of the causes (effects) are confronted and finally overcome. This is what smart villages do: they attempt to break the cycle at different points of the process. 


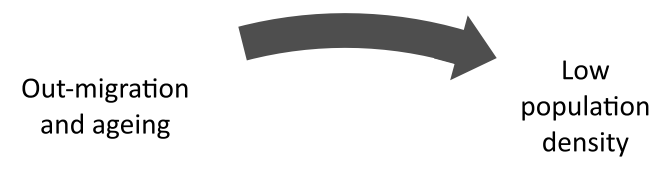

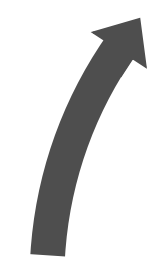

Fewer jobs

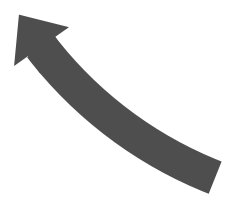

Figure 1. Cycle of rural decline

Source: ENRD 2018.

\section{Understanding Smart Villages in Context}

Given the fact that the Smart Villages approach is mainly about how to act in the changing rural reality and react to the challenges it entails, and not about the specific fields of action (though it facilitates digitalisation and innovativeness), the definition of a "smart village" is not as clear as one may expect. However, this is not a weak point; on the contrary, it exemplifies the diversity of rural areas and highlights the problems they share. The development of a definition that could be adapted to different contexts of actions was one of the tasks of the Thematic Group on Smart Villages, which was established under the ENRD's contact point in Brussels and has been in operation since 2017. ${ }^{3}$ The group has also been discussing the changes in rural development policy and opportunities for providing support for smart villages, exchanging experience and best practices in smart rural development, and serving as a forum for dialogue of various rural stakeholders.

3 https://enrd.ec.europa.eu/enrd-thematic-work/smart-and-competitive-rural-areas/smart-villages (access: September 2018). 
The rural areas in Europe are diverse. Programming their development, and thus developing a policy that equally satisfies different groups of stakeholders in different rural regions of the continent, is thus difficult and calls for flexible solutions. Such solutions can be provided with the deployment of approaches to the rural development management which are oriented on the place, needs of communities, and co-creation. Smart Villages aspires to be such a flexible approach.

As a result, the definition of smart villages focuses on specific communities' qualities and attitudes (cf. Zavratnik, Kos and Stojmenova Duh 2018). Being a smart village means (ENRD 2018):

- using digital technology when appropriate. However, this is just one of the tools used;

- thinking beyond the village itself. Despite the fact that the initiatives are taken at local level, smart villages understand that they exist surrounded by the countryside, other villages, towns and cities. They also activate these linkages;

- building new forms of cooperation and alliances. These are: between farmers and other rural actors; between municipalities; between the private sector and civil society. They also integrate the bottom-up and top-down approaches;

- thinking for yourself. There is no standard model for a smart village or a set of tools it uses. That is why smart villages take stock of local assets, use the best available knowledge and thanks to that take the initiative to shape the surrounding reality.

Work on the development of what smart villages mean started with these points in mind. As part of the Pilot Project on Smart Eco-Social Villages, consultation on the working definition was launched. The backbone of this definition was taken from the EU Action for Smart Villages, and it states that they are "rural areas and communities which build on their existing strengths and assets as well as on developing new opportunities", where "traditional and new networks and services are enhanced by means of digital, telecommunication technologies, innovations and the better use of knowledge" (EC 2017, p. 3), Members of the TG, among others with an interest, then expressed their opinions. The work is still in progress (as of September 2018). ${ }^{4}$

In spite of the fact that the definition itself has not yet been developed, some conclusions about it can be drawn, and it is worth highlighting two points to sum up the considerations on this issue in the paper. First, the definition has so far

4 The project has been granted by the European Commission (Directorate-General for Agriculture and Rural Development) to the consortium of Ecorys, Origin for Sustainability and R.E.D. in December 2017, and it will be completed by April 2019. The progress in the development of the definition of smart villages can be traced at: http://pilotproject-smartvillages.eu (access: September 2018). 
remained open, and it will probably remain so after the work is completed, so that it can take the diversity of rural regions of Europe on board, and thus the diversity of their needs. Nonetheless, it sets a new framework for thinking and acting pro rural development. Second, "smart" does not have to mean realising high-tech projects, projects that concentrate on innovative, infrastructural developments, or projects that address only the needs specific to advanced rural areas (communities) in terms of economic development.

The Smart Villages approach faces various problems as they arise. For this reason it fits into the current approach to the programming of development, according to which one size does not fit all (Ward and Brown 2009). It is also in line with New Rural Paradigm, which aims to raise the competitiveness of rural areas, valorise rural assets and exploit unused rural resources (OECD 2006). The Paradigm, like the Rural Development Position (cf. Baldock et al. 2001), pinpoints the fact that rural areas are not solely agricultural, so that investments and not subsidies are needed to boost their development. Both also see the place for different rural actors. However, what the Paradigm adds is that all levels of government should be involved in the process, thus it advocates the need for complementarity between local, regional, national, and supra-national policies (OECD 2006). This also alters the position and role of regional and local governments, which-together with smart communities- should take the initiative in shaping rural development - a multilevel, multi-actor and multi-faceted process (van der Ploeg et al. 2000).

\section{Support for Smart Villages}

\subsection{EU Action for Smart Villages in Detail}

The EU Action for Smart Villages, of which the TG is part, started in 2017 and is a strategic approach, which frames policies, tools, and instruments fostering smart villages. All of these constitute both financial and non-financial futureproof means of support.

The TG on Smart Villages first and foremost recommends using the existing Rural Development Programme tools and instruments. It draws attention to local action groups (LAGs) since they frequently initiate actions at local level, and, in a sense, make them more open and accessible for local people (after all, these are the people who are at the heart of Smart Villages). ${ }^{5}$ For this reason, Measure 19: Support for the LEADER local development (CLLD) is at the forefront, as it aids

5 It is worth pointing out that some potential of this kind can be seen in the village renewal groups and regional rural renewal programmes in Poland. 
implementation of projects addressed to local communities and tailored to their needs.

Smart villages can also seek support in other RDP instruments. These are the following measures: Basic services and village renewal in rural areas (M07), Cooperation (M16), and-partly-Farm and business development (M06). These correspond to the role of innovativeness in the development process and various forms of relations between stakeholders, as indicated above. These also put the supply of services centre stage - a key aspect of the quality of life in rural areas that the rural smart development acts in favour of and revitalises. According to the TG, the financial instruments that can be used depend on what a smart village is on the local level, because the solutions used are intended to solve problems of a particular village, and not to impose the meaning of the "smart village" itself or to set the directions for action.

Having that in mind, one should not forget that smart villages can seek help beyond the RDP (European Agricultural Fund for Rural Development). For instance, the EU Cohesion Policy provides the European Regional Development Fund and Cohesion Fund, both focused, among others, on research and innovation, business competitiveness, investment in the fields of the environment, transport, urban-rural linkages, and administrative capacity, to mention only those which are closely related to the rural smart development (EC 2017).

In the context of research and innovation, selected infrastructure facilities and transport, Horizon 2020 (the EU Framework Programme for Research and Innovation) and Connecting Europe Facility funds should also be mentioned. This can foster rural smart development under the Societal Challenge 2 (especially the call on rural renaissance), while the latter supports the development of transEuropean networks in the fields of transport and digital services (EC 2017).

It can be concluded that the EU Action for Smart Villages does not create a new instrument of support. This results from the fact that existing policies, tools and instruments do enable smart villages to seek opportunities. Consequently, the centre of attention is somewhat shifted to non-financial instruments and the role of stakeholders, with the regional and local governments playing a role, as was identified in the New Rural Paradigm (OECD 2006) and is presented in the next subsection of the paper.

Apart from EU funds, the action on smart villages can be reinforced from national or regional sources. The specifics of this aid varies so widely among the member states (and regions) that it was not possible to present them in the paper if it was to be kept concise and informative at the same time. For the same reason, these were not discussed at the meetings of the TG. However, some of the examples 
of smart rural projects presented in the next section of the paper may provide a limited illustration of them.

As stated above, the EU Action for Smart Villages consists not only of financial but also non-financial support. A couple of actions to promote Smart Villages deserve further attention. Before the TG on Smart Villages, there was the TG on Smart Rural Business, which provided knowledge, expertise and identification of best practices in rural business. To achieve its goals, the current TG has been collaborating with and building on a number of the previously existing initiatives to maintain the continuity of the work on smart rural development.

Knowledge transfer has been effected via workshops, seminars and conferences dedicated to smart-village-related issues (EC 2017). These were for instance: the ENRD Seminar on "Revitalising Rural Areas through Business Innovation" (March 2017), Seminar on New Data Driven Business Development (June 2017), Conference on Innovation in Agriculture and Rural Development (October 2017), ENRD Workshop on LEADER Innovation (November 2017), 11th OECD Rural Development Conference on Enhancing Rural Innovation (co-organised with the support of the European Commission; April 2018), ENRD Workshop "Making Rural Areas More Attractive for Young People" (May 2018), and, finally, ENRD Seminar on "Smart Villages" (May 2018). ${ }^{6}$

Some pilot projects on smart villages have also been launched. Beginning in 2016, there has been the project on Smart Rural Transport Areas (SMARTA), where the focus is on sustainable shared mobility interconnected with public transport in rural areas. In the following year, the project on Smart Eco-Social Villages started. The specific focus is connectivity and digital solutions in rural areas, and to explore the characteristics of smart villages in-depth, as mentioned above.

\subsection{Local Level and Role of Regional and Local Governments} (and Partly of the EU)

In my view, in times of EU financial support for rural development, it seems that at local level it is becoming more important to build the capacity of public administration, strengthen governance, and hence to create a proper environment and good climate for implementing the Smart Villages approach. This stems from the fact that smart villages involve innovativeness (and, vice versa, innovativeness strengthens smart villages), and innovativeness is inherently connected to risk (as is any change). For this reason, establishing an environment for smart

${ }^{6}$ For the past and upcoming events (co)organised by the ENRD and partners see: https://enrd. ec.europa.eu/news-events_en. 
villages demands not only accepting risk, but also changing the way we think about success and failure in realising projects. Innovations should not encounter resistance just because it is "safer" to carry out standard projects (Idziak and Wilczyński 2003), such as those whose course and effects can be $100 \%$ planned and predicted. Innovativeness in rural projects in Poland is rare (Wolski 2018). Such projects are rather deviations from rules, which are preserved by inflexible financial frameworks, administrative and legal issues, and formal and informal relations between local government, rural communities and representatives of nongovernmental organisations and the business sector. Hence, innovations demand that beneficiaries (both formal and ultimate) abandon the standard scheme of applying and using of external sources. Nevertheless, since the beneficiaries have a limited influence on what the funding scheme looks like, the role of the EU in making it more flexible can also be seen (I have included more on the evolution of the EU policies in the summary).

In view of the competence and scope of responsibilities, a local (regional) government plays a key role in this process. In this context, a smart village is the place where the local government fulfils duties to its community, so that it has opportunities to express its less standard ideas and to develop creative interactions aimed at generating new ideas. This is possible only if the local government endeavours to act against problems, thus building trust. Local government should also support and take part in implementing community-led actions using various means of communication, for instance, ICT solutions or real participation. In doing so, the local (regional) government builds a competitive advantage where seemingly there is no advantage at all; this occurs if the local government bases itself on both the needs of local communities (which express deficits) and stakeholders' ideas to meet them (which are assets) as well. As a result, while addressing such needs they use the potential of the local community, which is the potential in itself because it further catalyses positive change. Such an alliance concentrates on grasping opportunities whenever possible and is based on local resources (see Ward et al. 2005 and the definition of smart village).

When a village follows the smart approach, it is based in a healthy financialinstitutional environment and network of horizontal and vertical relations, all of which always coincide. Smart villages then enhance their learning process and cooperation. Subsidiarity is introduced where possible and appropriate in order to create such a good climate for the approach to development. 


\section{Examples of Smart Rural Development Projects}

To illustrate Smart Villages in practice, this section provides three examples of projects realised in EU member states responding to various different challenges. ${ }^{7}$ Relating to the cycle of rural decline, one may note how they address different elements of it. The first example, Digital Villages, act in favour of developing the market for local products and services, thus they make the local economy more sustainable. The second example, COWOCAT_RURAL, strengthens local enterprises through co-working. In the long run, it attracts people to work and live in rural areas, hence counteracting emigration. The third and last example, Rezo Pouce, has found an alternative for public transport which, due to low population density in some rural areas, lacks the critical number of users for cost-effectiveness.

\subsection{Digital Villages (Digitale Dörfer)}

The project has been implemented since 2015 in the villages of Eisenberg, Göllheim, and Betzdorf-Gebhardshain, Rhineland-Palatinate, Germany. It focuses on using digitalisation to create new opportunities for the development of depopulating villages. Specifically, it aims to provide the ICT infrastructure, and its central element is an internet platform (Hess 2018).

The platform serves a couple of functions. First, it is an online shop which sells local products (and thus strengthens the local economy). The products are delivered door-to-door by volunteers who live in the villages, which strengthens relations in the communities and at the same time minimises operating costs. Second, it is a medium where service providers and clients find each other: the former increase their reach and can more easily enter the market, while the latter can declare an interest in particular services or in hiring a professional. Finally, the platform has communication tools, thanks to which the villagers can share ideas and arrange meetings; it can thus be called a social medium. The platform is accessible for the municipalities participating in the project, hence cooperation between them is intensified.

The living lab approach has been used to realise the project (Hess 2018). This presupposes that-from the planning stage to the business model development stage-all the stakeholders work on concepts, prototypes and solutions that are all

7 Many more examples of projects implemented in Europe in accordance with the approach discussed can be found at the TG on Smart Villages website: https://enrd.ec.europa.eu/enrd-thematic-work/smartand-competitive-rural-areas/smart-villages and on the Smart Villages Portal: https://enrd.ec.europa.eu/ smart-and-competitive-rural-areas/smart-villages/smart-villages-portal/projects-initiatives_en (access: September 2018). 
grounded, designed and evaluated (Figure 2). Consequently, if necessary, mistakes made at any phase are corrected, and concepts, prototypes or solutions are improved.

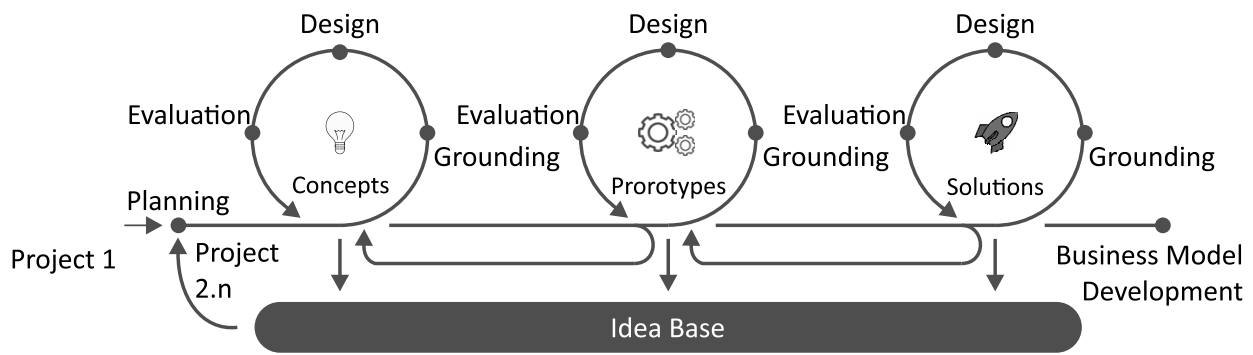

Figure 2. Living lab approach

Source: Hess 2018.

Despite the fact that trial and error is an effective way of learning and coming up with new solutions, it may involve costs; any mistake and the need to correct it may do this. However, this is no less than what I outlined earlier in explaining the role of regional and local governments and the EU in making the application and use of external sources more flexible. Re-tailoring some of the tools and instruments may be both necessary and beneficial, given the fact that Smart Villages is a relatively new approach.

Digital Villages were financed by the Ministry of Internal Affairs and Sports of Rhineland-Palatinate and the Fraunhofer Institute for Experimental Software Engineering (IESE). Since they were not supported by EU funds, I understand that one may conclude that the EU tools and instruments were-for some reasoninappropriate or just inaccessible for this kind of project. On the other hand, to the same extent it may prove that national/regional sources can also be engaged in the smart rural development. ${ }^{8}$

\subsection{COWOCAT_RURAL - Promoting co-working in rural Catalonia (COWOCAT - Xarxa d'espais i ecosistemes de coworking en entorns rurals de Catalunya)}

In order to boost rural economic development, the project aims to create coworking spaces in rural areas of Catalonia (Estany 2018). Co-working, which is sharing office space and ICT facilities, significantly lowers the cost of business, especially in case of small enterprises and in the initial stage of operation. At

8 More information about the project can be found at: https://www.digitale-doerfer.de (in German). 
the same time, it fosters networking, so that entrepreneurs who cooperate and share experience increase their chances of entering and - more importantly -staying in the market.

From 2014 to 2016, 14 co-working spaces were created, and 130 entrepreneurs have been running their businesses making use of them. The offices are also promoted as a part of the project. For instance, meetings for the co-workers from the rural and urban areas are organised. This helps activate further cooperation and has an impact on rural-urban economic linkages. Some of the co-workers-but not only them-have been working as "regional animators" whose aim is to help select and support the professionals who will be later linked to a specific co-working space. Such animators also stimulate cooperation projects and seek to bring investors or clients to the developed projects (Estany 2018).

If used to broaden opportunities for running a business, co-working may also encourage people to remain in rural areas. Such spaces demand access to highspeed broadband (or building such an infrastructure) and other services. However, what is more important is to have motivated professionals (Estany 2018), which again proves the role of the human factor. To conclude, success in projects of this kind relies on how hard (infrastructure) and soft (human) components are mixed and how their use is planned at different stages of the project (first, there must be the infrastructure, but then there must be the motivated users).

The project was co-financed by the European Agricultural Fund for Rural Development (EAFRD), M19: Support for the LEADER local development (CLLD) and the Ministry of Agriculture, Livestock, Fisheries and Food of the Government of Catalonia. ${ }^{9}$

\subsection{Rezo Pouce - Daily Hitchhiking (Rezo Pouce - Lautostop au quotidien)}

A digital app and mobility scheme to promote car sharing and hitchhiking has been developed to respond to poor transport facilities and the last-mile problem in the rural areas of France. The tool works first by the interested municipalities joining the initiative, and then by the villagers from these municipalities signing up to the website to access to the app. Finally, logged-on drivers and passengers can spot each other since the app works in real time. Apart from the software, there are also hitching spots where they meet. In order to identify each other, the drivers have stickers on their car windscreens and the passengers have badges. The scheme is adapted for short and medium journeys, usually daily (Marples and Rozes 2018).

\footnotetext{
9 For more information about the project, visit: http://www.cowocatrural.cat (in Catalonian).
} 
The application was developed by the Transdev Group and the Macif Foundation. Now it is free of charge and managed by a social enterprise. Participating municipalities (more than 1,500 as of May 2018), with the LEADER programme support (EAFRD, M19: Support for the LEADER local development (CLLD)) for some of them, cover the cost of the system (Marples and Rozes 2018).

Although similar solutions were previously known, some features of the Rezo Pouce project are unique: the scale of the project and the reach of the app, the specifics of the areas it reaches, and the safety of the journey it ensures. It also exemplifies how to engage non-governmental organisations, social enterprises and the public sector to reduce costs and make solutions available without limit. ${ }^{10}$

\section{Conclusions}

The Smart-Villages approach is above all about people and initiatives they carry out. Smart villages are smart communities representing certain qualities and attitudes which enable them to react to challenges driven by the changes in rural areas. It demands that rural communities change how they think of the development and what they do in order to develop. This is crucial for the communities to ignite a proactive attitude and to embed into the dynamic world where, among others, knowledge and technology lead the way. However, these are not just aspects that make the approach innovative, because it is also an approach that can be adapted regardless of features of the specific rural area.

The approach is also under discussion in EU policy. The Directorate-General for Regional and Urban Policy (DG REGIO), acting under the European Commission, is paving the way. The Cohesion Policy-the main investment policy of the EU-is evolving in terms of supporting local-level actions. It is planned that the post2020 policy will include: achieving results in a simple, flexible and cost-effective manner; higher national co-financing; faster implementation and closure; higher complementarity between financial instruments; and a simplification of funding schemes (Stavropoulos 2018). Despite the fact that the above was formulated mostly in terms of the Cohesion Policy, two implications for rural smart development emerge. First, together with the EAFRD and European Maritime and Fisheries Fund (EMFF), the Cohesion Policy funds constitute European structural and investment funds. Hence, taking into account the general trend to make the EU policies more complementary, it is inferred that the changes presented may lead to a broader evolution in EU policies. Second, as mentioned above, smart villages can be supported by the Cohesion Policy itself (and not only via the RDP).

10 More information available at: https://www.rezopouce.fr (in French). 
Further to these, I note that the Smart Villages approach responds to the way policy is evolving, and it is a real alternative to the way we have so far conceived of increasing the quality of life in rural areas. However, it seems that the approach calls for making the existing instruments more flexible and tailored (which applies both to the openness of EU policy to non-standard projects and the availability of the national/regional sources).

The EU policy is not without its faults when it comes to supporting such approaches (for instance, a funding scheme which is rigid and too results-oriented, the growing weight of bureaucracy and over-regulation, to mention only a few of those indicated by the TG). However, it provides tools and instruments for financing smart villages. In addition, local governments should play a role if the approach is to have an impact on rural life. This is why I have noted that Smart Villages is also pragmatic. It refers to the existing tools and instruments, but, at the same time, it optimises their use/role at local level.

Making use of the available resources and their own potential, smart villages can break the cycle of rural decline: they seek opportunities for revitalising rural services (including public ones), explore linkages with cities, towns and other villages, act in support of digitalisation of rural areas (including provision of the ICT infrastructure), and, in total, respond to demographic changes in the countryside. Smart Villages is thus to answer what is still unanswered - problems as they are.

\section{Bibliography}

Bajer M. (2012). Technologie informacyjno-komunikacyjne jako narzędzie ograniczania dysparytetów społeczno-ekonomicznych wsi w Unii Europejskiej. Wieś i Rolnictwo, $154(1), 65-84$.

Baldock D., Dwyer J., Lowe P., Petersen J.E., Ward, N. (2001). The nature of rural development: Towards a sustainable integrated rural policy in Europe. London: Institute for European Environmental Policy.

BBC (British Broadcasting Company) (2014). Social and Economic Changes in Rural Areas in MEDCs, http://www.bbc.co.uk/schools/gcsebitesize/geography/rural_environments/ changes_rural_areas_medcs_rev1.shtml [access: September 2018].

Boyle P., Halfacree K. (eds.) (1998). Migration into Rural Areas: Theories and Issues. John Wiley and Sons.

Crouch D. (2006). Tourism, consumption and rurality. In: P. Cloke, T. Marsden, P. Mooney (eds.), Handbook of Rural Studies (pp. 355-364). London: Sage.

EC (European Commission) (2017). https://ec.europa.eu/agriculture/sites/agriculture/files/ rural-development-2014-2020/looking-ahead/rur-dev-small-villages_en.pdf [access: September 2018].

ENRD (European Network for Rural Development) (2018). Smart Villages. Revitalising Rural Services. EU Rural Review, 26. Luxembourg: Publications Office of the European Union. 
Estany G. (2018). Cowocat_Rural - Promoting Cooworking in Rural Catalonia. Poster on the ENRD Seminar on "Smart Villages: Revitalising Rural Services through Social and Digital Innovation", Brussels, 22 ${ }^{\text {nd }}$ May 2018.

Galdeano-Gómez E., Aznar-Sánchez J.A., Pérez-Mesa J.C. (2011). The complexity of theories on rural development in Europe: An analysis of the paradigmatic case of Almería (South-East Spain). Sociologia Ruralis, 51 (1), 54-78.

Halfacree K. (2012). Diverse ruralities in the 21st century: From effacement to (re-)invention. In: L.J. Kulcsar, K.J. Curtis (eds.), International Handbook of Rural Demography (pp. 387-400). International Handbooks of Population, 3. Springer Netherlands.

Hess S. (2018). Digital Villages: Germany. Poster on the ENRD Seminar on "Smart Villages: Revitalising Rural Services through Social and Digital Innovation”, Brussels, $22^{\text {nd }}$ May 2018.

Idziak W., Wilczyński R. (2003). Odnowa wsi: Przestrzeń, ludzie, działania. Warsaw: Fundacja Programów Pomocy dla Rolnictwa FAPA.

Marples A., Rozes B. (2018). Rezo Pouce. Poster on the ENRD Seminar on "Smart Villages: Revitalising Rural Services through Social and Digital Innovation”, Brussels, $22^{\text {nd }}$ May 2018.

Marsden T. (1999). Rural futures: The consumption countryside and its regulation. Sociologia Ruralis, 39 (4), 501-520.

Murdoch J., Pratt A. (1993). Rural studies: Modernism, postmodernism and the „post rural”. Journal of Rural Studies, 9, 411-427.

Naldi L., Nilsson P., Westlund H., Wixe F. (2015). What is smart rural development? Journal of Rural Studies, 40, 90-101.

OECD (Organisation for Economic Co-operation and Development) (2006). The New Rural Paradigm: Policies and Governance. Paris: OECD.

Ploeg J.D., van der, Renting H., Brunori G., Knickel K., Mannion J., Marsden T., de Roest K., Sevilla-Guzmán E., Ventura F. (2000). Rural Development: From Practices and Policies towards Theory. Sociologia Ruralis, 40 (4), 391-408.

Smart Villages: https://enrd.ec.europa.eu/enrd-thematic-work/smart-and-competitive-rural-areas/smart-villages_en [access: September 2018].

Stavropoulos E. (2018). Integrated Approaches for Smart Villages. Presentation on the ENRD Seminar on "Smart Villages: Revitalising Rural Services through Social and Digital Innovation", Brussels, $22^{\text {nd }}$ May 2018.

Terluin I. (2003). Differences in economic development in rural regions of advanced countries: an overview and critical analysis of theories. Journal of Rural Studies, 19, 327-344.

Visvizi A., Lytras M.D. (2018). Rescaling and refocusing smart cities research: From mega cities to smart villages. Journal of Science and Technology Policy Management, 9 (2), 126-133.

Ward N., Atterton J., Kim T.-Y., Lowe P., Phillipson J., Thompson N. (2005). Universities, the Knowledge Economy and 'Neo-Endogenous Rural Development'. Newcastle upon Tyne: University of Newcastle upon Tyne, Centre for Rural Economy Discussion Paper Series, $1,1-15$. 
Ward N., Brown D.L. (2009). Placing the rural in regional development. Regional Studies, 43(10), 1237-1244.

Wolski O. (2018). Problem (nie)innowacyjności w projektach odnowy wsi. Acta Universitas Lodziensis, Folia Geographica Socio-Oeconomica, 31, 17-37.

Zavratnik V., Kos A., Stojmenova Duh E. (2018). Smart villages: Comprehensive review of initiatives and practices. Sustainability, 10(8), 2559-2573.

Zwolińska-Ligaj M., Guzal-Dec D., Adamowicz M. (2018). Koncepcja inteligentnego rozwoju lokalnych jednostek terytorialnych na obszarach wiejskich regionu peryferyjnego na przykładzie województwa lubelskiego. Wieś i Rolnictwo, 179(2), 247-280.

\section{Inteligentne wioski w polityce Unii Europejskiej. Jak połączyć innowacyjność z pragmatyzmem?}

Streszczenie: Inteligentne wioski są podejściem do rozwoju obszaru wiejskich, które obecnie jest dyskutowane przez Unię Europejską w ramach prac Europejskiej Sieci na rzecz Rozwoju Obszarów Wiejskich (ENRD). Od 2017 roku prace te prowadzone są w ramach utworzonej Grupy Tematycznej (GT) ds. Inteligentnych Wiosek. GT współuczestniczy w opracowaniu definicji inteligentnych wiosek, dyskutuje zmiany polityki rozwoju obszarów wiejskich i możliwości wsparcia inteligentnych wiosek, a także stanowi forum dla dialogu między różnymi grupami interesariuszy oraz platformę wymiany doświadczeń i najlepszych praktyk inteligentnego rozwoju. Artykuł przedstawia zarys dyskusji, jaka miała miejsce podczas wybranych spotkań GT, a także wskazuje - gdzie właściwe - jej akademickie podłoże. Jego celem było zaprezentowanie podejścia Smart Villages w kontekście polityki Unii Europejskiej. Stąd prezentuje on pokrótce genezę tej dyskusji i dylematy dotyczące definiowania inteligentnych wiosek, a także wskazuje role lokalnych samorządów i UE $\mathrm{w}$ tworzeniu warunków odpowiednich dla wdrożenia tego typu podejścia. W pracy zawarto także przykłady projektów inteligentnego rozwoju obszarów wiejskich. Inteligentne wioski stanowią alternatywny sposób myślenia o podnoszeniu jakości życia na wsi. Wydają się także korespondować z kierunkiem, w jakim ewoluuje polityka unijna. Niemniej, podejście to wciąż wymaga lepszego dopasowania narzędzi i instrumentów finansowych, co tyczy się zarówno polityki UE, jak i źródeł krajowych (regionalnych). Istotna jest także rola lokalnych władz samorządowych w procesie ich wsparcia.

Słowa kluczowe: inteligentne wioski (smart villages), inteligentny rozwój obszarów wiejskich, polityka rozwoju obszarów wiejskich, polityka Unii Europejskiej (UE), Europejska Sieć na rzecz Rozwoju Obszarów Wiejskich (ENRD). 